\title{
Aspir (Carthamus tinctorius L.)'de Verim, Yağ ve Oleik Asit İçeriği Yüksek Hat Geliştirme Islahı
}

\author{
*Hasan BAYDAR Sabri ERBAŞ
}

Süleyman Demirel Üniversitesi, Ziraat Fakültesi, Tarla Bitkileri Bölümü, Isparta
*Sorumlu yazar e-posta (Corresponding author e-mail): hasanbaydar@sdu.edu.tr

Öz

Bu araştırmada, "Dinçer 5-118” (dikensiz-kırmızı çiçekli) ve "Montola 2000" (dikenli-sarı çiçekli) çeşitlerinin melezlenmesi ile elde edilen popülasyonlar ve ileri generasyon hatları tohum verimi, yağ içeriği, oleik ve linoleik asit oranları bakımından değerlendirilmiştir. Ebeveynler $\left(P_{1}\right.$ ve $\left.P_{2}\right)$ ve erken generasyonlar $\left(F_{1}\right.$ ve $\left.F_{2}\right)$ arasındaki ilişkilerden gidilerek tohum verimi, yağ içeriği, oleik ve linoleik asit oranları için sırasıyla \%55.2, \%67.6, \% 99.4 ve \%99.3 oranlarında kalıtım derecesi değerleri tahmin edilmiştir. Ayrıca $\mathrm{F}_{1}$ döllerinde tohum verimi için önemli ve olumlu heterosis değeri (\%44.64) elde edilmiştir. Pedigri seleksiyonu ile $F_{4}$ kademesine taşınan 64 adet ileri hat arasından yüksek tohum ve yağ verimi, yüksek yağ ve oleik asit içeriği, düşük kabuk oranı, yüksek 1000 tane ağırlığı ve yüksek hasat indeksi bakımından ebeveynlerine göre daha üstün özellikler taşıyan 16 adet ileri hat $\left(F_{4}-16, F_{4}-23, F_{4}-31, F_{4}-48, F_{4}-74, F_{4}-82, F_{4-88}, F_{4}-95, F_{4-103}, F_{4}-107, F_{4}-121, F_{4-}\right.$

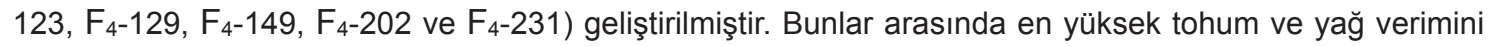
sırasıyla 225.3 ve $72.5 \mathrm{~kg} /$ da ile $\mathrm{F}_{4}-149$ nolu hat, en yüksek yağ oranını \%36.70 ile $\mathrm{F}_{4-123}$ nolu hat, en yüksek oleik asit ve en düşük linoleik asit oranlarını sırasıyla \%79.53 ve \%12.46 ile $\mathrm{F}_{4}-107$ hat vermiştir.

Anahtar Kelimeler: Aspir, melezleme ıslahı, pedigri seleksiyonu, kalıtım derecesi, hat geliştirme

\section{Line Development Breeding for High Yield, Oil and Oleic Acid Content in Safflower (Carthamus tinctorius L.)}

\begin{abstract}
In this research, populations and advanced safflower lines derived from a cross between "Dinçer 5-118" (spineless and red flower) and "Montola 2000" (spiny and yellow flower) were evaluated for seed yield, oil content, oleic or linoleic acid contents. Broad sense heritabilities from the relationship between parents $\left(P_{1}\right.$ and $\left.P_{2}\right)$ and early generations $\left(F_{1}\right.$ and $F_{2}$ ) were estimated for seed yield, oil content, oleic and linoleic acid contents as 55.2, 67.6, 99.4 and $99.3 \%$, respectively. In addition, high and positive heterosis value (44.64\%) was obtained from $F_{1}$ progenies for seed yield. Superior 16 pure lines $\left(F_{4}-16, F_{4}-23, F 4-31, F_{4}-48, F_{4-74}, F_{4-}\right.$ 82, $F_{4}-88, F_{4}-95, F_{4}-103, F_{4}-107, F_{4}-121, F_{4}-123, F_{4}-129, F_{4}-149, F_{4}-202$ and $\left.F_{4}-231\right)$ with high seed and oil yields, high oil and oleic acid contents, low husk ratio, high 1000 seed weight and high harvest index were developed among the 64 advanced lines from $\mathrm{F}_{4}$ population derived by using pedigree method of breeding. The highest seed and oil yields ( 225.3 and $72.5 \mathrm{~kg} / \mathrm{da}$, respectively) from line $F_{4}-149$, the highest oil content (36.70\%) from line $\mathrm{F}_{4}-123$, the highest oleic acid and the lowest linoleic acid contents $(79.53$ and $12.46 \%$, respectively) from line $\mathrm{F}_{4}-107$ were observed.
\end{abstract}

Keywords: Safflower, cross breeding, pedigree selection, heritability, line improvement

\section{Giriş}

A spir (Carthamus tinctorius L., Compositeae), tohumlarında \%25-45 arasında ve \%90'ı doymamış yağ asitlerinden (oleik ve linoleik asit) oluşan yağı ile önemli bir yağ bitkisidir. Yağ bitkileri ıslahında nihai ıslah amaçları, yüksek tohum ve yağ verimi ile klasik yağ asitleri kompozisyonu modifiye edilmiş yeni ve üstün çeşitler geliştirmektir. Türkiye'de ıslah çalışmaları ile birçok aspir çeşidi geliştirilmiş ise de bunların tohum verimleri ve yağ oranları halen istenilen düzeylerde değildir. Ayrıca oleik asit tipi yağlara olan ilginin giderek önem kazanmasıyla birlikte, 
yüksek linoleik asitli $(\mathrm{HL})$ çeşitler yanında yüksek oleik asitli $(\mathrm{HO})$ aspir çeşitlerin de geliştirilmesine de intiyaç vardır. Nitekim özellikle ABD'de yüksek linoleik asit içeren çeşitler ('Morlin' gibi) yanında, yüksek oleik asit içeren çeşitler de ('Montola' gibi) geliştirilmiş, yağının stabilitesi artırılmış ve böylelikle endüstriyel kullanım alanı daha da genişlemiştir (Baydar ve Erbaş 2007).

Diğer kültür bitkilerinde olduğu gibi yağ bitkilerinde de verim artışına etki eden genetik ve çevresel faktörler genel olarak kalite üzerine olumsuz etkilerde bulunmaktadır. Örneğin yağ oranı yüksek olan çeşitlerin tohum verimleri genellikle düşüktür. Çünkü yağ sentezlemek için yüksek miktarda enerjiye intiyaç vardır; tohum sayısı ve iriliği gibi verimi doğrudan etkileyen özelliklerin azalması pahasına. İşte bu nedenle, sürekli yüksek yağ oranı için yapılan seleksiyonlar ile elde edilen hat ve çeşitlerin tohum verimleri genelde düşüktür. Yağ bitkilerinde yine benzer olumsuz ilişkiler yağ oranı ile protein oranı arasında, oleik asit oranı ile linoleik asit oranı arasında ortaya çıkmakta; yağ oranı arttıkça protein oranı, oleik asit oranı arttıkça linoleik asit oranı azalmaktadır. Ancak bu tür olumsuz ilişkilerin (linkage) kırıldığı genetik varyantları elde etmek olasıdır (Baydar ve Erbaş 2014).

Aspir, yüksek oranda kendine döllenen bir bitkidir (böcek ve rüzgar yoğunluğuna bağlı olarak \%0-20 oranında yabancı döllenebilmektedir) ve diğer birçok kültür bitkisinde de olduğu gibi en etkin genetik varyasyon yaratma yollarından başında melezleme gelmektedir. İşte bu araştırmada, düşük yağ ve yüksek linoleik asit içeren 'Dinçer 5-118' çeşidi ile yüksek yağ ve yüksek oleik asit içeren 'Montola 2000' çeşidi gibberellik asit ile kimyasal polen kısırlığı yöntemi uygulanarak melezlenmiş ve ilk açılım kuşağından $\left(F_{2}\right)$ itibaren pedigri seleksiyon metodu uygulanarak yüksek tohum ve yağ verimi, yüksek yağ içeriği ve yüksek oleik asit oranına sahip ileri hatlar elde edilmeye çalışılmıştır.

\section{Materyal ve Yöntem}

2009-2013 yılları arasında 5 yıl süresince Süleyman Demirel Üniversitesi Ziraat Fakültesi Tarla Bitkileri Bölümü'nde yürütülmüş olan bu araştırmada, 'Dinçer 5-118' (ㅇ, dikensiz tablalıkırmızı çiçekli, yağ içeriği \%25-30 ve linoleik asit oranı \%70-75) ve 'Montola 2000' ( ${ }^{\lambda}$, dikenli tablalı-sarı çiçekli, yağ içeriği \%35-40 ve oleik asit oranı \%70-80) aspir çeşitlerinin melezlenmesi ile elde edilmiş olan $F_{1}, F_{2}, F_{3}$, ve $\mathrm{F}_{4}$ melez soyları materyal olarak kullanılmıştır.

2009 yllında, 'Dinçer 5-118' ve 'Montola 2000' ebeveynleri arasında gibberellik asit ile kimyasal erkek kısırlık yaratılarak melezleme yapılmıştır (Baydar ve Gökmen 2003). 2010 yılında, $F_{1}$ tohumları ekilerek $F_{1}$ bitkileri yetiştirilmiş, $F_{1}$ bitkileri arasında dikensiz olanlar (melez olmayanlar) çiçeklenme döneminden önce sökülerek uzaklaştırılmış ve böylece \%100 melez bitkiler bırakılmıştır (dikenlilik dikensizlik üzerine dominanttır ve kalıtımı monogeniktir). Gerçek melez $F_{1}$ tohumları izolasyonlu koşullarda kendileme yapılarak $F_{2}$ populasyonu oluşturulmuştur. 2011 yılında, $F_{1}$ ve $\mathrm{F}_{2}$ generasyon dölleri ile ebeveynler [Dinçer 5-118 $\left(P_{1}\right)$ ve Montola $\left.2000\left(P_{2}\right)\right] 22$ Mart 2011 tarihinde $5 \mathrm{~m}$ uzunluğunda, $50 \mathrm{~cm}$ sıra arası ve $20 \mathrm{~cm}$ sıra üzerine ekilmişler, olgunlaşmayla birlikte tarımsal ve kalite özelliklerin kalıtımı 20 adet $P_{1}, 20$ adet $P_{2}, 17$ adet $F_{1}$ ve 256 adet $F_{2}$, yağ asitlerinin kalıtımı için 16 adet $P_{1}, 6$ adet $P_{2}$, 5 adet $F_{1}$ ve 64 adet $F_{2}$ bitkisinde belirlenmiştir. Ayrıca açılma gösteren $F_{2}$ populasyonunda tabla dikenliliği ve çiçek rengi için fenotipik açılma oranları belirlenmiş ve $x^{2}$ testine göre uyumluluğu test edilmiştir. $x^{2}=\Sigma[($ Gözlenen Beklenen)2 / Beklenen]. $F_{1}$ döllerinde incelenen tarımsal ve kalite özelliklerinde ebeveyn ortalaması (EO) ve üstün ebeveyne (ÜE) göre heterosis ve heterobeltiyosis oranları belirlenmiştir: Heterosis $(\%)=\left[\left(F_{1}-E O\right) / E O\right] x$ 100 ve Heterobeltiyosis $(\%)=\left[\left(F_{1}-\right.\right.$ UE $\left.) / U E\right] x$ 100. Ebeveyn ve melez soylarda generasyonlar arası ilişkilerden gidilerek geniş anlamda kalıtım dereceleri belirlenmiştir (Allard, 1966; Demir, 1975): $V_{C}=\left(V_{P 1}+V_{P 2}+V_{F 1}\right) / 3, V_{G}=V_{F 2}-V_{C}, H=$ $V_{G} / V_{P}=V_{G} / V_{F 2} \quad\left(H\right.$ : Kalıtım derecesi, $V_{c}$ : çevre varyansı, $V_{G}$ : genetik varyans, $V_{P}$ : fenotip varyansı, $V_{P 1}$ : Dişi ebeveyn varyansı, $V_{P 2}$ : Erkek ebeveyn varyansı, $V_{F 1}$ : $F_{1}{ }^{\prime} l e r i n$ varyansI, $V_{F 2}$ : $\mathrm{F}^{2}$ lerin varyansı). Ayrıca incelenen her bir özelliğe ilişkin ortalama $(x)$, varyans $(\mathrm{V})$, standart sapma (S), standart hata (Sx) ve varyasyon katsayısı (CV) gibi temel istatistik parametreler SAS (1998) istatistik programı yardımıyla hesaplanarak populasyon analizi yapılmıştır.

2012 yılında, $F_{2}$ populasyonundan dikenlilik ve çiçek rengi gibi iki temel morfo-genetik özellik 
bakımından ortaya çıkan 9:3:3:1 digenik fenotipik açılım oranı temel alınarak 256 adet melez bitki seçilmiş ve her bir bitkiye pedigri numarası (1-144 Dikenli-Kırmızı, 145-192 Dikenli-Sarı, 193-240 Dikensiz-Kırmızı ve 241256 Dikensiz-Sarı) verilerek $F_{3}$ populasyonunu (A hatları) oluşturmak üzere ebeveynleri ile birlikte ayrı ayrı döl sıralarında $(5 \mathrm{~m}$ uzunluğunda) $50 \times 20 \mathrm{~cm}$ sıklıkta yetiştirilmişlerdir. $F_{3}$ populasyonunu oluşturan $A$ hatlarında her birinden 5 adet bitki (toplam 256 x $5=1280$ adet) toprak seviyesinden biçilerek hasat edilmiş, ıslah amaçları göz önünde bulundurularak, transgresif açılımların da etkisiyle ebeveyn ortalamaları üzerinde olan yüksek tohum verimine, yüksek yağ içeriğine ve yüksek oleik asit oranına sahip olan döl sıralarından elit tek bitki seleksiyonu yapılmış ve ebeveynlerine göre üstün 64 adet hat (B hatları) belirlenmiştir.

2013 yılında, $F_{4}$ kademesini oluşturan 64 adet B hattı, ebeveynleri ile birlikte 22 Mart 2013 tarihinde tesadüf blokları deneme desenine göre 3 tekerrürlü olarak ekilmişlerdir. Seçilen hatların tohumları sınırlı olduğundan, her tekerrürdeki her bir hat 1 sıra ile temsil edilmişlerdir. $5 \mathrm{~m}$ uzunluğundaki deneme parsellerine $50 \mathrm{~cm}$ sıra arası ve $20 \mathrm{~cm}$ sıra üzeri verilerek 3-5 cm derinlikte ekim yapılmış, ekimle birlikte deneme parsellerine $10 \mathrm{~kg} / \mathrm{da}$ DAP gübresi, bitkilerin sapa kalkma döneminde ise $15 \mathrm{~kg} / \mathrm{da}$ AS gübresi atılmış, kuru tarım koşullarında deneme kurulduğundan sulama yapılmamıştır. Olgunlaşmayla birlikte (16-22 Ağustos 2013) her parselde her B hattını temsil eden 5 adet bitki toprak seviyesinden biçilerek hasat ve harman edilmiş, bazı önemli tarımsal (bitki boyu, dal sayısı, tabla sayısı, tabla çapı, tablada tohum sayısı, hasat indeksi, 1000 tane ağırlığı, tohum ve yağ verimi) ve kalite (kabuk oranı, NMR yağ oranı ve GC/MS yağ asitleri kompozisyonu) özellikleri belirlenmiş, elde edilen veriler tesadüf blokları deneme desenine göre SAS (1998) istatistik paket programında analiz edilmiştir.

\section{Bulgular ve Tartışma}

Aspirde tabla dikenliliği ve çiçek rengi, melezleme sonrasında fenotipik ayrımda kullanılan önemli morfolojik markırlardır. 'Dinçer 5-118' (Kırmızı-Dikensiz) x 'Montola 2000' (SarıDikenli) melezi olan $F_{1}$ döllerinin kendilenmesiyle elde edilen $F_{2}$ generasyonu döllerinde çiçek rengi ve dikenlilik karakterleri için fenotipik açılma oranları $\mathrm{X}^{2}$ testi ile kontrol edilmiştir (Çizelge 1). Sonuç olarak, her iki özelliğin ayrı ayrı monogenik kalıtım (3:1 fenotipik açılım oranlarına uyumlu) gösterdiği, dikenlilik karakterinin (D) dikensizlik karakteri (d) üzerine, kırmızı çiçek renkliliği karakterinin (K) sarı çiçek renkliliği karakteri (k) üzerine dominant olduğu belirlenmiştir. Ayrıca $F_{2}$ generasyonunda her iki özelliğin birlikte dihibrid fenotipik açılım oranı (9 D.K. : 3 D.kk : 3 ddK. : 1 ddkk) verdiği ve elde edilen beklenen oranın gözlenen oranla uyumlu olduğu $(P<0.05)$ tespit edilmiştir (Çizelge 1).

'Dinçer 5-118' ve 'Montola 2000' ebeveynleri ile melez soylarında bitki başına tohum verimi, yağ oranı, oleik asit oranı ve linoleik asit oranına ilişkin varyans analizleri, genetik parametreler ve geniş anlamda kalıtım derecesi değerleri Çizelge 2'de sunulmuştur. Tohum verimi için genetik varyans değeri $\left(V_{G}=32.74\right)$ çevre varyansı değerinden $\left(\mathrm{V}_{c ̧}=26.60\right)$ nispeten daha yüksek çıkmış, heterosis değeri \%44.64 ve geniş anlamda kalıtım derecesi \%55.2 olarak tahmin edilmiştir (Çizelge 2). Aspirde tohum

Çizelge 1. Dinçer 5-118 (Kırmızı-Dikensiz) x Montola 2000 (Sarı-Dikenli) melezlemesinde çiçek rengi-tabla dikenliliği için $X^{2}$ testi

Table 1. $X^{2}$ test for flower color - spininess of Dinçer 5-118 (spineless and red flower) and Montola 2000 (spiny and yellow flower) crosses

\begin{tabular}{lcccc}
\hline \multirow{2}{*}{ Fenotipik sınıflar } & \multicolumn{2}{c}{$\mathrm{F}_{2}$ generasyonu } & \multirow{2}{*}{$(\mathrm{G}-\mathrm{B})^{2} / \mathrm{B}$} & \multirow{2}{*}{$\operatorname{Pr}>\mathrm{X}^{2}$} \\
\cline { 2 - 3 } & Gözlenen $(\mathrm{G})$ & Beklenen $(\mathrm{B})$ & & 0.35 \\
\\
\cline { 2 - 3 } Dikenli-Kırmızı & 758 & $741.9(9)$ & 0.02 & \\
Dikenli-Sarı & 245 & $247.3(3)$ & & \\
Dikensiz-Kırmızı & 249 & $247.3(3)$ & 0.01 & \\
Dikensiz-Sarı & 67 & $82.5(1)$ & 2.91 & \\
\hline Toplam & 1319 & 1319 & 3.29 & 0.35 \\
\hline
\end{tabular}

Serbestlik derecesi $=4-1=3, X^{2}$ cetvel $(0.05$ için $)=7.82$

Degree of freedom $=4-1=3, X^{2}$ table $($ for 0.05$)=7.82$ 
verimi ile ilgili melez azmanlığı ve kalıtım üzerine yapılan araştırmalarda; Ramachandram and Goud (1981) tohum veriminin kalıtımında eklemeli genler ve kısmi olarak dominant genlerin baskın olduğunu Ghongade ve ark. (1993) ile Reddy et al. (2004) aspirde tohum veriminin sırasıyla $\% 47.5$ ve $\% 65.4$ oranında orta düzeyde bir kalıtım belirlemişlerdir.
Ebeveyn ve soyların yağ oranına ilişkin genetik parametreler incelendiğinde; aspirde yağ oranının kalıtımında genetik faktörlerin çevre faktörlerine göre daha belirleyici olduğu $\left(V_{C}=1.52\right.$ ve $\left.V_{G}=3.17\right)$ belirlenmiş, \%5.04 oranında düşük bir heterosis değeri ve \%67.6 oranında yüksek bir geniş anlamda kalıtım derecesi değeri tespit edilmiştir (Çizelge 2).

Çizelge 2. "Dinçer 5-118 x Montola 2000" melezlemesinde tohum verimi, yağ oranı, oleik asit oranı ve linoleik asit oranı için populasyon analizi ve genetik parametreler

Table 2. Population analysis and genetic parameters for seed yield, oil, oleic acid and linoleic acid contents of "Dinçer 5-118 x Montola 2000" crosses

\begin{tabular}{lcccc}
\hline \multirow{2}{*}{ Tohum verimi (g/bitki) } & \multicolumn{4}{c}{ Ebeveyn ve soylar } \\
\cline { 2 - 5 } & $\mathrm{P}_{1}$ & $\mathrm{P}_{2}$ & $\mathrm{~F}_{1}$ & $\mathrm{~F}_{2}$ \\
\hline Varyasyon sınırları (min-max) & $11.2-27.3$ & $6.8-18.7$ & $9.3-26.4$ & $5.6-45.4$ \\
Ortalama \pm standart hata & $16.7 \pm 1.16$ & $10.6 \pm 0.90$ & $19.8 \pm 1.87$ & $16.0 \pm 0.48$ \\
Standart sapma & 4.64 & 3.59 & 6.73 & 7.70 \\
Varyans & 21.57 & 12.91 & 45.32 & 59.34 \\
Varyasyon katsayısı (\%) & 27.70 & 33.80 & 34.00 & 48.20 \\
\hline
\end{tabular}

\begin{tabular}{|c|c|c|c|c|}
\hline $\begin{array}{c}\text { Çevre varyansı } \\
\left(\mathrm{V}_{C}\right)\end{array}$ & $\begin{array}{c}\text { Genotip varyansı } \\
\left(V_{\mathrm{G}}\right)\end{array}$ & $\begin{array}{c}\text { Kalıtım derecesi } \\
(\%)\end{array}$ & $\begin{array}{l}\text { Heterosis } \\
(\%)\end{array}$ & $\begin{array}{c}\text { Heterobeltiyosis } \\
(\%)\end{array}$ \\
\hline 26.60 & & 55.2 & $44.64^{* *}$ & $18.23^{* *}$ \\
\hline \multirow{2}{*}{ Yağ oranı (\%) } & \multicolumn{4}{|c|}{ Ebeveyn ve soylar } \\
\hline & $\mathrm{P}_{1}$ & $\mathrm{P}_{2}$ & $\mathrm{~F}_{1}$ & $\mathrm{~F}_{2}$ \\
\hline Varyasyon sınırları (min-max) & $24.5-28.2$ & $31.1-35.6$ & $29.9-33.1$ & $22.9-36.5$ \\
\hline Ortalama \pm standart hata & $26.4 \pm 0.33$ & $33.5 \pm 0.38$ & $31.4 \pm 0.24$ & $31.1 \pm 0.14$ \\
\hline Standart sapma & 1.36 & 1.41 & 0.85 & 2.16 \\
\hline Varyans & 1.84 & 1.98 & 0.73 & 4.68 \\
\hline Varyasyon katsayısı (\%) & 5.10 & 4.20 & 2.70 & 7.00 \\
\hline $\begin{array}{c}\text { Çevre varyansı } \\
\left(\mathrm{V}_{c ̧}\right)\end{array}$ & $\begin{array}{c}\text { Genotip varyansı } \\
\left(V_{G}\right)\end{array}$ & $\begin{array}{c}\text { Kalıtım derecesi } \\
(\%)\end{array}$ & $\begin{array}{c}\text { Heterosis } \\
(\%)\end{array}$ & $\begin{array}{c}\text { Heterobeltiyosis } \\
(\%)\end{array}$ \\
\hline 1.52 & 3.17 & 67.6 & $5.04^{*}$ & $-6.07^{*}$ \\
\hline \multirow{2}{*}{ Oleik asit oranı (\%) } & \multicolumn{4}{|c|}{ Ebeveyn ve soylar } \\
\hline & $\mathrm{P}_{1}$ & $\mathrm{P}_{2}$ & $F_{1}$ & $\mathrm{~F}_{2}$ \\
\hline Varyasyon sınırları (min-max) & $8.64-12.21$ & $73.95-78.91$ & $18.23-35.16$ & $8.68-77.85$ \\
\hline Ortalama \pm standart hata & $10.84 \pm 0.28$ & $76.89 \pm 0.74$ & $26.98 \pm 3.02$ & $25.95 \pm 2.86$ \\
\hline Standart sapma & 1.26 & 1.82 & 6.76 & 22.89 \\
\hline Varyans & 1.59 & 3.31 & 45.73 & 523.97 \\
\hline Varyasyon katsayısı (\%) & 11.60 & 2.42 & 25.13 & 88.24 \\
\hline $\begin{array}{c}\text { Çevre varyansı } \\
\left(\mathrm{V}_{\mathrm{C}}\right)\end{array}$ & $\begin{array}{c}\text { Genotip varyansı } \\
\left(V_{\mathrm{G}}\right)\end{array}$ & $\begin{array}{c}\text { Kalıtım derecesi } \\
(\%)\end{array}$ & $\begin{array}{c}\text { Heterosis } \\
(\%)\end{array}$ & $\begin{array}{c}\text { Heterobeltiyosis } \\
(\%)\end{array}$ \\
\hline 3.28 & & 99.4 & $-38.50^{* *}$ & $-64.91^{* *}$ \\
\hline \multirow{2}{*}{ Linoleik asit oranı (\%) } & \multicolumn{4}{|c|}{ Ebeveyn ve soylar } \\
\hline & $\mathrm{P}_{1}$ & $\mathrm{P}_{2}$ & $\mathrm{~F}_{1}$ & $\mathrm{~F}_{2}$ \\
\hline Varyasyon sınırları (min-max) & $75.96-79.92$ & $11.79-16.61$ & $53.27-71.12$ & $13.11-81.22$ \\
\hline Ortalama \pm standart hata & $77.95 \pm 0.35$ & $13.84 \pm 0.76$ & $62.12 \pm 3.12$ & $62.97 \pm 2.75$ \\
\hline Standart sapma & 1.41 & 1.87 & 6.97 & 22.02 \\
\hline Varyans & 2.00 & 3.49 & 48.57 & 484.73 \\
\hline Varyasyon katsayısı (\%) & 1.82 & 13.52 & 11.23 & 35.04 \\
\hline $\begin{array}{c}\text { Çevre varyansı } \\
\left(\mathrm{V}_{\mathcal{C}}\right)\end{array}$ & $\begin{array}{c}\text { Genotip varyansı } \\
\left(V_{\mathrm{G}}\right)\end{array}$ & $\begin{array}{c}\text { Kalıtım derecesi } \\
(\%)\end{array}$ & $\begin{array}{c}\text { Heterosis } \\
(\%)\end{array}$ & $\begin{array}{c}\text { Heterobeltiyosis } \\
(\%)\end{array}$ \\
\hline 3.42 & $\begin{array}{c}\left(V_{\mathrm{G}}\right) \\
481.31\end{array}$ & 99.3 & $35.37^{* *}$ & $-20.30^{* *}$ \\
\hline
\end{tabular}

${ }^{*} \mathrm{P}<0.05,{ }^{* *} \mathrm{P}<0.01$

${ }^{* *} P<0.05,{ }^{* *} P<0.01$ 

(Carthamus tinctorius L.)"

Çizelge 3. 64 adet aspir hattının ve bunların ebeveynleri olan Dinçer 5-118 ve Montola 2000 aspir çeşitlerinin tarımsal ve teknolojik özellikleri

Table 3. Agricultural and technological properties of 64 safflower lines and their parents Dinçer 5-118 and Montola 2000 varieties

\begin{tabular}{|c|c|c|c|c|c|c|c|}
\hline \multirow{2}{*}{ Özellikler } & \multirow[b]{2}{*}{ Ortalama } & \multirow{2}{*}{ Değişim aralığı- } & \multicolumn{2}{|c|}{ Hatlar } & \multicolumn{2}{|c|}{ Ebeveynler } & \multirow{2}{*}{$\begin{array}{l}\text { Her iki ebeveyni de } \\
\text { geçen hat sayısı }\end{array}$} \\
\hline & & & Min. & Max. & Dinçer & Montola & \\
\hline İlk çiçeklenme (gün) & 101.2 & $94.7-106.0$ & $F_{4}-88$ & $F_{4}-228$ & 101.0 & 104.3 & 15 (erkenci) - 3 \\
\hline $\begin{array}{l}\% 50 \text { çiçeklenme } \\
\text { (gün) }\end{array}$ & 109.0 & $102.3-114.0$ & $F_{4}-88$ & $\mathrm{~F}_{4}-228$ & 107.7 & 112.0 & $\begin{array}{c}7 \text { (erkenci) }-3 \\
\text { (geççi) }\end{array}$ \\
\hline Bitki boyu (cm) & 57.2 & $48.3-67.2$ & $F_{4}-129$ & $F_{4}-17$ & 60.7 & 60.7 & $\begin{array}{c}16 \text { (kısa) - } 48 \\
\text { (uzun) }\end{array}$ \\
\hline $\begin{array}{l}\text { Dal sayısı } \\
\text { (adet/bitki) }\end{array}$ & 4.6 & $3.5-5.8$ & $F_{4}-227$ & $F_{4}-174$ & 5.0 & 4.4 & $\begin{array}{c}12 \text { (dal sayısı daha } \\
\text { fazla) }\end{array}$ \\
\hline $\begin{array}{l}\text { Tabla sayısı } \\
\text { (adet/bitki) }\end{array}$ & 7.8 & $5.4-12.8$ & $F_{4-76}$ & $F_{4}-196$ & 7.8 & 10.1 & $\begin{array}{c}3 \text { (tabla sayısı daha } \\
\text { fazla) }\end{array}$ \\
\hline Tabla çapı (cm) & 23.7 & $21.0-26.6$ & $F_{4}-253$ & $F_{4}-48$ & 23.9 & 23.2 & $\begin{array}{c}28 \text { (tabla çapı daha } \\
\text { fazla) }\end{array}$ \\
\hline Hasat indeksi (\%) & 28.1 & $18.8-34.8$ & $F_{4}-183$ & $F_{4}-149$ & 29.8 & 23.5 & $\begin{array}{l}23 \text { (hasat indeksi } \\
\text { daha fazla) }\end{array}$ \\
\hline $\begin{array}{l}1000 \text { tane ağırlığı } \\
\text { (g) }\end{array}$ & 42.0 & $33.4-54.1$ & $F_{4}-129$ & $\mathrm{~F}_{4}-88$ & 45.1 & 36.5 & $\begin{array}{l}15 \text { (bin tane ağırlığı } \\
\text { daha fazla) }\end{array}$ \\
\hline Kabuk oranı (\%) & 50.0 & $46.2-53.6$ & $F_{4}-218$ & $\mathrm{~F}_{4}-67$ & 55.5 & 52.4 & $\begin{array}{l}58 \text { (kabuk oranı } \\
\text { daha düşük) }\end{array}$ \\
\hline $\begin{array}{l}\text { Tohum verimi } \\
\text { (kg/da) }\end{array}$ & 140.2 & $74.5-225.3$ & $F_{4}-129$ & $F_{4}-149$ & 148.9 & 125.9 & $\begin{array}{l}26 \text { (tohum verimi } \\
\text { daha fazla) }\end{array}$ \\
\hline Yağ verimi (kg/da) & 44.3 & $24.0-72.5$ & $F_{4}-129$ & $F_{4}-149$ & 39.8 & 40.5 & $\begin{array}{c}39 \text { (yağ verimi daha } \\
\text { fazla) }\end{array}$ \\
\hline Yağ oranı (\%) & 33.0 & $30.0-36.7$ & $F_{4}-67$ & $F_{4}-123$ & 27.8 & 33.6 & $\begin{array}{c}21 \text { (yağ oranı daha } \\
\text { fazla) }\end{array}$ \\
\hline Palmitik asit (\%) & 6.10 & $4.66-7.23$ & $F_{4}-123$ & $F_{4}-11$ & 6.49 & 6.61 & $\begin{array}{l}16 \text { (palmitik daha } \\
\text { fazla) }\end{array}$ \\
\hline Stearik asit (\%) & 2.60 & $1.67-4.50$ & $F_{4}-107$ & $\mathrm{~F}_{4}-253$ & 2.31 & 3.25 & $\begin{array}{c}6 \text { (stearik daha } \\
\text { fazla) }\end{array}$ \\
\hline Oleik asit (\%) & 32.10 & $8.54-79.53$ & $F_{4}-87$ & $F_{4}-107$ & 14.35 & 65.42 & 9 (oleik daha fazla) \\
\hline Linoleik asit (\%) & 57.70 & $12.46-80.71$ & $F_{4}-107$ & $F_{4}-87$ & 75.55 & 23.41 & $\begin{array}{c}23 \text { (linoleik daha } \\
\text { fazla) }\end{array}$ \\
\hline
\end{tabular}

Aspirde yağ oranı için Ragab and Friedt (1992) \%15-24 arasında, Shivani ve ark. (2010) ise \%-1.18-6.85 arasında heterosis değerleri elde etmişlerdir. Aspirde yağ oranı için tahminlenen kalıtım derecelerinin orta ve yüksek düzeylerde olduğu rapor edilmektedir. Nitekim Ghongade et al. (1993) düşük oranda (\%32.8), Ramachandram and Goud (1981) ise yüksek oranda (\%92.0) kalıtım derecesi belirlemişlerdir.

Oleik asit, 'Dinçer 5-118' çeşidinde \%8.6412.21 (ortalama \%10.84), 'Montola 2000' çeşidinde \%73.95-78.91 (ortalama \%76.89) ve $F_{1}$ dölleri \%18.23-35.16 (ortalama \%26.98) arasında varyasyon göstermiştir. Beklendiği şekilde $F_{2}$ populasyonunda ebeveyn ve diğer melez soylara göre daha geniş bir oleik asit varyasyon aralığı ortaya çıkmış (\%8.68-77.85), populasyon ortalaması \%25.95 olarak gerçekleşmiştir.

Diğer taraftan $F_{1}$ döllerinde oleik asit oranı bakımından önemli ve negatif bir heterosis ve heterobeltiyosis değerleri (sırasıyla \%-38.50** ve $\%-64.91^{* *}$ ) belirlenmiştir (Çizelge 2). Hamdan et al. (2009), düşük oleik asit (\%18.1) ve yüksek oleik asit $(\% 86.6)$ içeren aspir genotiplerinin melezlenmesi ile elde ettikleri $F_{1}$ döllerinin ortalama \%28.4 oranında oleik asit içerdiğini, $F_{2}$ döllerinin ise $\% 10.4-37.9$ ve \%81.3-87.2 oranında monogenik kalıtıma uygun iki farklı oleik asit grubunun meydana geldiğini rapor etmişlerdir. Oleik asit için genotip varyansı $\left(V_{G}=520.69\right)$ çevre varyansından $\left(V_{c ̧}=3.28\right)$ daha büyük değerde bulunmuş, \%99.4 oranında oldukça yüksek oranda bir kalıtım derecesi tespit edilmiştir (Çizelge 2). Diğer taraftan melez populasyonlarda düşük oranda oleik asit oranına sahip olanların daha fazla olması, linoleik asitten sorumlu genlerin oleik asit üzerine dominant etki gösterdiğini işaret etmektedir (Fernandez-Martinez and Knowles 1987; Joksimoviç et al. 2006). Bunun yanında Golkar et al. (2011) oleik asidin kalıtımında eklemeli genler etkili olduğunu ve yüksek kalıtım derecesi (geniş ve dar anlamda sırasıyla, $F_{1}$ 'de $0.92-0.81$ ve $F_{2}$ 'de 0.93-0.73) verdiğini bildirmişlerdir. 
Knowles and Hill (1964), aspirde oleik asit sentezinin bir gen lokusunda yer alan eklemeli etkili üç ayrı allel gen (Ol, o1 ${ }^{1}$ ve ol) tarafından kontrol edildiğini, Hamdan et al. (2009) ise ol allellerinin çoğunun negatif etki gösterdiğini, oleik asit içeriği yüksek hatların geliştirilmesinde genlerdeki oleik asit içeriğine pozitif etkisi olan allellerin etkinliğinin artırılması gerektiğini vurgulamışlardır. Knowles and Hill (1964), OIOI allel gen çiftinin yüksek linoleik asit (\%7580)/düşük oleik asit (\%10-15) içeriğinden, ol1ol1 allel gen çiftinin orta seviyede oleik asit (\%3550) ve orta seviyede linoleik asit (\%42-54) içerdiğinden, buna karşılık olol allel gen çiftinin düşük linoleik asit (\%12-30)/yüksek oleik asit (\%64-83) içeriğinden sorumlu olduğunu rapor edilmiştir. Ayrıca Olol ${ }^{1}$ allellerini taşıyan genotiplerin $\% 10-15$ oleik asit $\% 70-75$ linoleik asit, Olol allellerini taşıyan genotiplerin \%18-35 oleik asit \% 60-75 linoleik asit ve ol1ol allellerini taşıyan genotiplerin ise $\% 55-63$ oleik asit \%3040 linoleik asit içerdiği saptanmıştır. Bu kaynaktan yola çıkarak; 'Dinçer 5-118' çeşidinin O/OI veya Olol ${ }^{1}$ allel gen çiftini, 'Montola 2000' çeşidinin olol allel gen çiftini, $\mathrm{F}_{1}$ döllerinin Olol gen çiftini ve $F_{2}$ döllerinin ise 37 'si OlOI veya Olol', 9'u Olol, 6'sı ol1ol1 ve 12'si olol allel gen çiftini taşıdığı tahmin edilmiştir. $F_{1}$ generasyon döllerinde ebeveyn ortalamasına göre linoleik asit oranı önemli ve pozitif heterosis değeri $\left(\% 35.37^{\star *}\right)$ ve üstün ebeveyne göre önemli ve negatif heterobeltiyosis değeri $\left(\%-20.30^{* *}\right)$ saptanmıştır (Çizelge 2). Aspirde oleik ve linoleik asit arasında bulunan yüksek oranda ve negatif korelasyon nedeniyle (Erbaş, 2012), oleik asit oranı için yüksek derecede önemli ve negatif heterosis değerinin, linoleik asit oranına yüksek derecede önemli ve pozitif olarak yansıdığı görülmektedir. Oleik asit gibi linoleik asidin de kontrolünde genetik faktörlerin $\left(V_{G}=\right.$ 481.31) çevresel faktörlere $\left(V_{c}=3.42\right)$ göre etkisi oldukça yüksek bulunmuş, $\% 99.3$ oranında yüksek bir kalıtım derecesi tespit edilmiştir (Çizelge 2). Çizelge 3'te, ebeveynlerine göre tohum verimi, yağ içeriği ve oleik asit oranı bakımından daha üstün bulunarak 256 melez bitki (A hatları) arasından seçilen ve pedigri seleksiyonu ile $\mathrm{F}_{4}$ kademesine götürülen 64 adet aspir hattının tarımsal ve teknolojik özellikleri sunulmuştur. Pedigri seleksiyonu ile $F_{4}$ populasyonuna taşınan 64 ileri hat (B hatları) arasından yüksek tohum ve yağ verimi, yüksek yağ ve oleik asit içeriği, düşük kabuk oranı, yüksek 1000 tane ağırlığı ve yüksek hasat indeksi bakımından ebeveynlerine göre daha üstün özellikler taşıyan 16 ileri hat $\left(F_{4}-16, F_{4}-23, F_{4}-31, F_{4}-48\right.$, $\mathrm{F}_{4-74}, \mathrm{~F}_{4}-82, \mathrm{~F}_{4}-88, \mathrm{~F}_{4}-95, \mathrm{~F}_{4}-103, \mathrm{~F}_{4}-107, \mathrm{~F} 4-$ $121, F_{4}-123, F_{4}-129, F_{4}-149, F_{4}-202$ ve $F_{4}-231$ ) belirlenmiştir. Bunlar arasında en yüksek tohum ve yağ verimi sırasıyla 225.3 ve $72.5 \mathrm{~kg} / \mathrm{da}$ ile $\mathrm{F}_{4}$-149 nolu hattan, en yüksek yağ oranı \%36.70 ile $\mathrm{F}_{4-1}-123$ nolu hattan, en yüksek oleik asit ve en düşük linoleik asit oranı (sırasıyla $\% 79.53$ ve $\% 12.46$ ) ile $\mathrm{F}_{4-107}$ hattan elde edilmiştir.

\section{Sonuç}

Hedeflenen ıslah amaçlarına uygun çeşit adayı $F_{5}$ kademesindeki 16 hat (C hatları) arasında özellikle tohum ve yağ verimi, 1000 tane ağırlığı, yağ oranı, oleik asit oranı ve linoleik asit oranına göre standart çeşitlerden üstün olan çeşit adayı 10 hattın (D hatları) 5 farklı lokasyonda (Isparta, Eskişehir, Konya, Edirne ve Şanlıurfa) adaptasyon ve stabilite denemeleri devam etmektedir.

\section{Teşekkür}

$\mathrm{Bu}$ araştırmaya destek sağlayan (10011110380) Türkiye Bilimsel ve Teknolojik Araştırma Kurumu (TÜBITAK) Tarım, Ormancılık ve Veterinerlik Araştırma Grubuna (TOVAG) teşekkür ederiz.

\section{Kaynaklar}

Allard R.W., 1966. Principles of Plant Breeding. John Wiley and Sons, Inc., New York, USA

Baydar H., Erbaş S., 2014. Yağ Bitkileri Bilimi ve Teknolojisi. Süleyman Demirel Üniversitesi Yayın No: 97 (ISBN: 978-9944-452-75-5)

Baydar H., Erbaş S., 2007. Türkiye'de Yemeklik Yağ ve Biyodizel Üretimine Uygun Aspir Islahı. 1. Ulusal Yağlı Tohumlu Bitkiler ve Biyodizel Sempozyumu. 28-31 Mayıs 2007, 378-386, Samsun

Baydar H., Gökmen O.Y., 2003. Hybrid seed production in safflower (Carthamus tinctorius L.) following the induction of male sterility by gibberellic acid. Plant Breeding, 122: 459-461

Demir İ., 1975. Genel Bitki Islahı, EUZF Yayınları, No: 212, EÜ Matbaası, Bornova, İzmir. 

(Carthamus tinctorius L.)"

Erbaş S., 2012. Melezleme Islahı ile Tohum Verimi, Yağ ve Oleik Asit İçeriği Yüksek Aspir (Carthamus tinctorius L.) Hatlarının Geliştirilmesi. SDÜ Fen Bilimleri Enstitüsü, Doktora Tezi, 132 Sayfa, Isparta

Fernandez-Martinez J., Knowles P.F., 1987. Inheritance of Seed Fatty Acid Composition in a Cross Between Domesticated and Wild Annual Sunflower. Genet. Agr., 41: 83-95

Futehally S., Knowles P.F., 1981. Inheritance of Very High Levels of Linoleic Acid in an Introduction of Safflower (Carthamus tinctorius L.) from Portugal. In: P. F. Knowles (ed.), Proceedings of First International Safflower Conference, University of California, Davis, CA, USA, 5661

Ghongade R.A., Navale P.A., Joshi B.P., 1993. Estimates of variability parameters in safflower. J. Agril. Uni., 18, 461-462

Golkar P., Arzani A., Rezaei A.M., 2011. Genetic Analysis of Oil Content and Fatty Acid Composition in Safflower (Carthamus tinctorius L.). J. Am. Oil Chem. Soc., 88: 975982

Hamdan Y.A.S., Vich B.P., Velasco L., FernandezMartinez J., 2009. Inheritance of High Oleic Acid Content in Safflower. Euphytica, 168: 6169
Joksimović J., Jovanka A., Marinković R., Jovanović D., 2006. Genetic control of oleic and linoleic acid contents in sunflower. Helia, 29 (44): 3340

Knowles P.F., Hill A.B., 1964. Inheritance of fatty acid content in the seed oil of a safflower introduction form Iran. Crop Science, 4: 406409

Ragab A.I., Friedt W., 1992. Heteresis and inbreeding depression for oil content and fatty acid composition in safflower (Carthamus tinctorius L.). Sesame and Safflower Newsletter, 7: 49-54

Ramachandram M., Goud J.V., 1981. Genetic analysis of seed yield, oil content and their components in safflower (Carthamus tinctorius L.). Theor. Appl. Genet., 60: 191195

Reddy M.V.S., Chand P., Vidyadhar B., Devi I.S.L., 2004. Estimation of genetic parameters for yield and its component in $\mathrm{F}_{4}$ generation of safflower (Carthamus tinctorius L.). Prog. Agric., 4 (1): 16-18

SAS Institute, 1998. INC SAS/STAT User's Guide Release 7.0, Cary, NC, USA 